\title{
Gender, Race/Ethnicity, and Representation in State Legislatures
}

\author{
Beth Reingold, Emory University
}

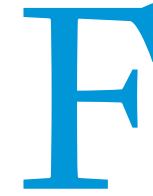
or most of the 400-year history of state legislatures, women and racial/ethnic minorities have been excluded as both voters and elected representatives. Although many African American men gained state-legislative office during Reconstruction and the first white women were elected in 1894, it was not until the Voting Rights Act (VRA) of 1965 and the second wave of feminist movements that women and minorities began gaining state-legislative seats in significant numbers. At the time, few political scientists noticed. By the 1990s, however, many began asking questions about gender, race/ ethnicity, and political representation and looking to the diversifying state legislatures for answers.

This article assesses the trends in and research on statelegislative diversity since the 1970s. It demonstrates how the study of state legislators has contributed significantly to our understanding of gender, race/ethnicity, and representation by leveraging the rich institutional and demographic variation that the states offer. Nonetheless, I argue, there is considerably more that scholars can learn by taking intersectional approaches to the study of race/ethnicity and gender and by paying more attention to institutional structures of power.

\section{DESCRIPTIVE REPRESENTATION}

In terms of gender, race, and ethnicity, state legislatures are much more diverse-or descriptively representative-today than in decades past. In 1973, shortly after passage of the VRA and congressional approval of the Equal Rights Amendment, roughly $97 \%$ of legislators were white men. Forty years later, in the wake of President Obama's 2012 reelection, two thirds were white men. The most recent data available show impressive gains for both women and racial/ethnic minorities. Since 1973, the number of women increased from 424 (6.4\% of all state legislators) to $1,874(25.4 \%)$ in 2018 ; the number of black legislators grew from 238 (3.1\%) to 686 (9.3\%) in 2016; and the number of Latinxs rose from $77(1 \%)$ to $326(4.4 \%)$ in $2017 .^{1}$ Between 1980 and 2015, the number of Asian Americans doubled (from $55 / 0.7 \%$ to $108 / 1.5 \%$ ) and, between the mid1990 s and 2018, the number of Native Americans tripled (from $26 / 0.3 \%$ to $81 / 1.1 \%$ ). ${ }^{2}$ In the wake of the second "Year of the Woman," women hold a record-breaking 2,112 (28.6\%) state-legislative seats in 2019-an unprecedented one-year increase of $3.2 \% .^{3}$

Equally remarkable is the variation in gender and racial/ ethnic diversity across the states. In 2018, women comprised anywhere from $11 \%$ to $40 \%$ of legislators in any given state.
Historically, Southern states elected the fewest women. Most of the growth in black representation, conversely, occurred in the same Southern legislatures. Five of the six states with the most African American legislators in 2016 (22\% to 29\%) are in the Deep South. Elsewhere, African Americans rarely comprise more than $10 \%$ of legislators; almost half $(44 \%)$ of non-Southern states have at least one chamber without any black legislators. Growth in Latinx, Asian American, and Native American representation has been more concentrated. As of 2018, five states claim half of all Latinx state legislators. Similarly, almost two thirds (64\%) of Native American legislators are found in only five states. Until the twenty-first century, at least $80 \%$ of Asian American legislators served in Hawaii. In 2015, 46\% served in Hawaii and half of the remainder (27\%) was found in only four other legislatures. Nonetheless, Latinxs, Asian Americans, and Native Americans alike have recently gained entry to more state legislatures.

\section{VARIATION IN DESCRIPTIVE REPRESENTATION}

State-legislative research has played an important role in understanding these changing patterns in diversity and the underrepresentation of women and minorities. This research frequently focuses on individual- or district-level analyses of the supply of and demand for (or support of) diverse candidates. But it is from the vantage point of the 50 states that we have learned the most about how political-opportunity structures, or various political and electoral institutions, channel and constrain the ambitions and fortunes of candidates.

Studies of state-legislative elections were among the first to establish the power of the VRA and the creation of single-member, majority-minority districts to increase minority representation, especially of African Americans in the South (Davidson and Grofman 1994). Thus, it is no coincidence that the number of black legislators has increased after almost every redistricting effort since the 1970 (Hicks et al. 2018); Latinx representation has kept pace with Latinx population growth; and variation in minority representation across state legislatures today now tracks variation in state minority populations (Hardy-Fanta et al. 2016).

As recent studies confirm, African American population size is the most powerful determinant of African American representation, and the size of the Latinx citizenry is the most powerful determinant of Latinx representation (Casellas 2011; Hicks et al. 2018; King-Meadows and Schaller 2006; Lublin et al. 2009; Preuhs and Juenke 2011). VRA-empowered minority electorates almost always elect minority candidates; 
little else seems to matter (but see Hicks et al. 2018). Given the overwhelming importance of district racial composition, legislative scholars must pay close attention to recent challenges to and reforms of state-redistricting institutions and their impact on racial representation.

The study of term limits is another prime example of the significant contributions of state-legislative research (Carey et al. 2006; Carroll and Jenkins 2001; Casellas 2011). and minority-group interests than their white male counterparts. Whereas congressional studies often focused on analyses of roll-call voting behavior, state studies offered several conceptual and research-design innovations.

Before the proliferation of NOMINATE scores, statelegislator surveys provided less constrained and more reliable cross-chamber measures of policy preferences and ideological predispositions, thereby verifying the theory that descriptive

\section{Studies of state-legislative elections were among the first to establish the power of the VRA and the creation of single-member, majority-minority districts to increase minority representation, especially of African Americans in the South (Davidson and Grofman 1994).}

Many early term-limit advocates expected that removing entrenched white male incumbents would open up opportunities for women and minorities. Yet, by establishing the absence of any significant or consistent effects of term limits on descriptive representation, researchers discovered that incumbency was not the only or even primary obstacle to gender and racial/ethnic political incorporation.

Women-and-politics scholars have studied how other state-level institutions structure the opportunities and incentives for descriptive representation. Multi-member districts have been consistently more beneficial to women than to minority representation (Darcy, Welch, and Clark 1994; Matland and Brown 1992; Rule 1992). Women may feel more confident running-and parties, voters, and others may feel more comfortable supporting them-when they are not the only possible winner. Studies show that legislative professionalism and strong state-party organizations inhibit women's representation for similar, gendered reasons: the representation enhances substantive representation (Button and Hedge 1996; Dodson and Carroll 1991; Epstein, Niemi, and Powell 2005; Thomas 1994). Surveys and interviews also enabled scholars to examine gender differences in selfreported legislative priorities and leadership styles, confirming that women legislators are more likely to care about women's issues and practice more egalitarian, consensus-building leadership (Dodson and Carroll 1991; Hardy-Fanta et al. 2016; Jewell and Whicker 1994; Reingold 2000; Rosenthal 1998; Thomas 1994). State scholars pioneered the use of bill sponsorship to gauge policy leadership and the agendasetting effects of descriptive representation (Bratton and Haynie 1999; Reingold 2000; Thomas 1994). To this day, these studies of legislative advocacy on behalf of women and minorities provide the strongest evidence of the link between descriptive and substantive representation (Osborn 2012; Rouse 2013). Most recently, randomized field experiments gauging the constituent responsiveness of state legislators

\section{Since the 1970s, the number of women of color elected has increased more rapidly than white women and men of color. Indeed, the increases in descriptive representation discussed previously have been driven largely by women of color, especially black women and Latinas (Hardy-Fanta et al. 2016).}

more powerful and competitive the office, the more likely that women's viability as candidates will be underestimated (Rosenthal 1998; Sanbonmatsu 2006; Squire 1992).

\section{IMPACT OF DESCRIPTIVE REPRESENTATION}

Armed with large numbers of diverse and relatively accessible elected representatives working in similar (yet different) institutions, state-legislative scholars have also contributed considerably to our understanding of how diversity affects legislative politics. For example, state research has enhanced our understanding of whether and how descriptive representatives provide more substantive representation of women's greatly enhanced our ability to isolate the causal effects of descriptive representation (Butler 2014).

State research has had an even more central role in our ability to gauge the relationship between descriptive and substantive representation at the aggregate, or institutional, level. Here, too, institutional variation in descriptive representation and policy outcomes across the states is key. Several studies demonstrated that racial and ethnic diversity in legislatures can foster policy change on behalf of minority interests or block proposals deemed harmful (Filindra and Pearson-Merkowitz 2013; Haynie 2001; Preuhs 2006). However, studies examining the impact of legislative women 
on policy outcomes report more mixed results (Crowley 2004; Kreitzer 2015; Weldon 2006). One of the most comprehensive studies found that the percentage of women legislators is associated with the adoption of only eight of 34 women-friendly policies examined; in three instances, the relationship was in the opposite direction (Cowell-Meyers and Langbein 2009).

\section{NEW DIRECTIONS}

State-legislative scholars are and should continue to be on the forefront of new directions in the study of gender, race/ ethnicity, and representation. First among these are more intersectional approaches that consider both race/ethnicity and gender as intersecting and interdependent forces that shape political institutions, processes, and outcomes (Smooth 2011). Frequently, these studies call attention to women of color who have been rendered invisible by the predominant "single-axis" approaches that group all women, all African Americans, and all Latinxs together (Crenshaw 1989). In doing so, this intersectional research can reveal how gender and race/ethnicity interact to affect the election, behavior, and impact of all individuals-raced women and gendered minorities alike.

Since the 1970s, the number of women of color elected has increased more rapidly than white women and men of color. Indeed, the increases in descriptive representation discussed previously have been driven largely by women of color, especially black women and Latinas (Hardy-Fanta et al. 2016). Political scientists have long noted these trends (Darcy and Hadley 1988; Prestage 1977; Rule 1992). However, only recently have we begun to examine the origins and impact of minority women's representation more thoroughly and intersectionally.

Bejarano (2013) and Scola (2014), for example, revealed how standard women-and-politics models-and, to a lesser extent, standard race-and-ethnic-politics models-do a better job identifying the institutional and demographic correlates of legislative officeholding for white women and men of color than for women of color. Other studies suggest that women of color are more ambitious and uniquely qualified campaigners (Bejarano 2013; Darcy and Hadley 1988; Hardy-Fanta et al. 2016). Yet, more research is needed before we can fully understand how the institutional environment channels that determination and skill to promote or inhibit the descriptive representation of minority women. Similarly, the growing literature on the representational behavior of women of color suggests that they often assume distinctive leadership roles in advocating for the interests of women, minorities, and minority women in particular (Bratton, Haynie, and Reingold 2006; Brown 2014; Reingold and Smith 2012). But, again, more research-especially state-legislative research-is needed to understand the complex institutional and intersectional dynamics of gender, race/ethnicity, and representation.

Despite the burgeoning research on the election and impact of women and minorities in state-legislative office, little attention has been given to their power within these institutions. What research there is presents a mixed picture. Women enjoy their "fair share" of party and committee leadership positions (Darcy 1996, 888; Jewell and Whicker 1994;
Thomas 1994) and black leadership is "virtually assured" as long as Democrats control the chamber (Button and Hedge 1996; Haynie 2001; Orey, Overby, and Larimer 2007, 637). Yet, reports of discrimination, exclusion, and stereotypingespecially in the higher ranks-abound, often in the same studies. Importantly, legislative leadership and the institutional power it confers may be a crucial link between descriptive and substantive representation, especially at the aggregate level (Preuhs 2006; Reingold and Smith 2012). Clearly, more research on state-legislative leadership selection is needed. The more attuned that research is to both the intersecting dynamics of race/ethnicity and gender and the varieties of legislative institutions, the more we will learn about the politics and processes of representation and inequality.

\section{NOTES}

1. National and state-level figures were provided by the Center for American Women and Politics; Joint Center for Political and Economic Studies; Carl Klarner (personal communication; August 6, 2018); National Association of Latino Elected and Appointed Officials; and Lemus (1974).

2. See various editions of the National Asian Pacific American Political Almanac (UCLA Asian American Studies Center, and Asian Pacific American Institute for Congressional Studies). Data on Native American state legislators were provided by McClain and Stewart $(1995,109)$ and the National Council of State Legislatures' State-Tribal Institute (personal communication, August 13, 2018).

3. Available at http://cawp.rutgers.edu/sites/default/files/resources/pressrelease-state-legislatures-results-2018.pdf.

\section{REFERENCES}

Bejarano, Christina E. 2013. The Latina Advantage. Austin: University of Texas Press.

Bratton, Kathleen A., and Kerry L. Haynie. 1999. "Agenda Setting and Legislative Success in State Legislatures: The Effects of Gender and Race." Journal of Politics 61: 658-79.

Bratton, Kathleen A., Kerry L. Haynie, and Beth Reingold. 2006. "Agenda Setting and African American Women in State Legislatures." Journal of Women, Politics \& Policy 28: 71-96.

Brown, Nadia E. 2014. Sisters in the Statehouse: Black Women and Legislative Decision Making. New York: Oxford University Press.

Butler, Daniel M. 2014. Representing the Advantaged: How Politicians Reinforce Inequality. New York: Cambridge University Press.

Button, James, and David Hedge. 1996. "Legislative Life in the 1990s: A Comparison of Black and White State Legislators." Legislative Studies Quarterly 21 (2): 199-218.

Carey, John M., Richard G. Niemi, Lynda W. Powell, and Gary F. Moncrief. 2006. "The Effects of Term Limits on State Legislatures: A New Survey of the 50 States." Legislative Studies Quarterly 31 (1): 105-34.

Carroll, Susan J., and Krista Jenkins. 2001. "Do Term Limits Help Women Get Elected?" Social Science Quarterly 82 (1): 197-201.

Casellas, Jason P. 2011. Latino Representation in State Houses and Congress. New York: Cambridge University Press.

Cowell-Meyers, Kimberly, and Laura Langbein. 2009. "Linking Women's Descriptive and Substantive Representation in the United States." Politics \& Gender 5 (4): 491-518.

Crenshaw, Kimberle. 1989. "Demarginalizing the Intersection of Race and Sex: A Black Feminist Critique of Antidiscrimination Doctrine, Feminist Theory, and Antiracist Politics." University of Chicago Legal Forum 139: 139-67.

Crowley, Jocelyn Elise. 2004. "When Tokens Matter.” Legislative Studies Quarterly 29: 109-36.

Darcy, Robert. 1996. "Women in the State Legislative Power Structure: Committee Chairs.” Social Science Quarterly 77: 888-98.

Darcy, Robert, and Charles D. Hadley. 1988. "Black Women in Politics: The Puzzle of Success." Social Science Quarterly 69: 629-45. 
Darcy, Robert, Susan Welch, and Janet Clark. 1994. Women, Elections, and Representation, second edition. Lincoln: University of Nebraska Press.

Davidson, Chandler, and Bernard Grofman. 1994. Quiet Revolution in the South: The Impact of the Voting Rights Act, 1965-1990. Princeton, NJ: Princeton University Press.

Dodson, Debra L., and Susan J. Carroll. 1991. Reshaping the Agenda: Women in State Legislatures. New Brunswick, NJ: Center for the American Woman and Politics.

Epstein, Michael J., Richard G. Niemi, and Lynda W. Powell. 2005. "Do Women and Men State Legislators Differ?” In Women and Elective Office: Past, Present, and Future, eds. Sue Thomas and Clyde Wilcox, second edition, 94-109. New York: Oxford University Press.

Filindra, Alexandra, and Shanna Pearson-Merkowitz. 2013. "Stopping the Enforcement Tide: Descriptive Representation, Latino Political Empowerment, and State-Level Immigration Policy." Politics $\mathcal{E}$ Policy 41 (6): 814-32.

Hardy-Fanta Carol, Pei-te Lien, Dianne M. Pinderhughes, and Christine Marie Sierra. 2016. Contested Transformation: Race, Gender, and Political Leadership in 21st-Century America. New York: Cambridge University Press.

Haynie, Kerry L. 2001. African American Legislators in the American States. New York: Columbia University Press.

Hicks, William D., Carl E. Klarner, Seth C. McKee, and Daniel A. Smith. 2018. "Revisiting Majority-Minority Districts and Black Representation." Political Research Quarterly 71 (2): 408-23.

Jewell, Malcolm E., and Marcia Lynn Whicker. 1994. Legislative Leadership in the American States. Ann Arbor: University of Michigan Press.

King-Meadows, Tyson, and Thomas F. Schaller. 2006. Devolution and Black State Legislators. Albany: State University of New York Press.

Kreitzer, Rebecca J. 2015. "Politics and Morality in State Abortion Policy." State Politics \& Policy Quarterly 15 (1): 41-66.

Lemus, Frank C. 1974. National Roster of Spanish-Surnamed Elected Officials. Los Angeles: Aztlán Publications.

Lublin, David, Thomas L. Brunell, Bernard Grofman, and Lisa Handley. 2009. "Has the Voting Rights Act Outlived Its Usefulness? In a Word, 'No."” Legislative Studies Quarterly 34 (4): 525-53.

Matland, Richard E., and Deborah Dwight Brown. 1992. "District Magnitude's Effect on Female Representation in U.S. State Legislatures." Legislative Studies Quarterly 17: 469-92.

McClain, Paula D., and Joseph Stewart, Jr. 1995. “Can We All Get Along?” Racial and Ethnic Minorities in American Politics. Boulder, CO: Westview.
Orey, Byron D’Andra, L. Marvin Overby, and Christopher Larimer. 2007. "African American Committee Chairs in U.S. State Legislatures." Social Science Quarterly 88: 619-39.

Osborn, Tracy L. 2012. How Women Represent Women: Political Parties, Gender, and Representation in the State Legislatures. New York: Oxford University Press.

Prestage, Jewell L. 1977. "Black Women State Legislators: A Profile.” In Portrait of Marginality: The Political Behavior of the American Woman, eds. Marianne Githens and Jewell L. Prestage, 401-18. New York: Longman.

Preuhs, Robert R. 2006. "The Conditional Effects of Minority Descriptive Representation: Black Legislators and Policy Influence in the American States." Journal of Politics 68 (3): 585-99.

Preuhs, Robert R., and Eric Gonzalez Juenke. 2011. "Latino U.S. State Legislators in the 1990s: Majority-Minority Districts, Minority Incorporation, and Institutional Position." State Politics \& Policy Quarterly 11 (1): 48-75.

Reingold, Beth. 200o. Representing Women: Sex, Gender, and Legislative Behavior in Arizona and California. Chapel Hill: University of North Carolina Press.

Reingold, Beth, and Adrienne R. Smith. 2012. "Welfare Policymaking and Intersections of Race, Ethnicity, and Gender in U.S. State Legislatures." American Journal of Political Science 56 (1): 131-47.

Rosenthal, Cindy Simon. 1998. When Women Lead: Integrative Leadership in State Legislatures. New York: Oxford University Press.

Rouse, Stella M. 2013. Latinos in the Legislative Process: Interests and Influence. New York: Cambridge University Press.

Rule, Wilma. 1992. "Multimember Legislative Districts: Minority and Anglo Women's and Men's Recruitment Opportunity." In United States Electoral Systems: Their Impact on Women and Minorities, eds. Wilma Rule and Joseph F. Zimmerman, 57-72. New York: Greenwood.

Sanbonmatsu, Kira. 2006. Where Women Run: Gender and Party in the American States. Ann Arbor: University of Michigan Press.

Scola, Becki. 2014. Gender, Race, and Office Holding in the United States: Representation at the Intersections. New York: Routledge.

Smooth, Wendy. 2011. "Standing for Women? Which Women? The Substantive Representation of Women's Interests and the Research Imperative of Intersectionality." Politics \& Gender 7 (3): 436-41.

Squire, Peverill. 1992. "Legislative Professionalism and Membership Diversity in State Legislatures." Legislative Studies Quarterly 17 (1): 69-79.

Thomas, Sue. 1994. How Women Legislate. New York: Oxford University Press.

Weldon, S. Laurel. 2006. "Women's Movements, Identity Politics and Policy Impact: A Study of Policies on Violence against Women in the 50 U.S. States." Political Research Quarterly 58 (1): 111-22. 